\title{
Ultrastructural and morphometric description of the ear skin and cartilage of two South American wild histricognate rodents (Dasyprocta leporina and Galea spixii) ${ }^{1}$
}

\begin{abstract}
Alexsandra F. Pereira ${ }^{2 *}$ (D) Leonardo V.C Aquino ${ }^{2}$, Matheus B. Nascimento ${ }^{2}$, Ferdinando V.F. Bezerra ${ }^{3}$, Alana A. Borges ${ }^{2}$, Érika A. Praxedes ${ }^{2}$ and Moacir F. Oliveira ${ }^{3}$

ABSTRACT.- Pereira A.F., Aquino L.V.C., Nascimento M.B., Bezerra F.V.F., Borges A.A., Praxedes E.A. \& Oliveira M.F. 2021. Ultrastructural and morphometric description of the ear skin and cartilage of two South American wild histricognate rodents (Dasyprocta leporina and Galea spixii). Pesquisa Veterinária Brasileira 41:e06775, 2021. Universidade Federal Rural do Semi-Árido, Av. Francisco Mota 572, Presidente Costa e Silva, Mossoró, RN 59625-900, Brazil. E-mail: alexsandra.pereira@ufersa.edu.br

Skin and cartilage have been the main source for the recovery of somatic cells to be used in conservation strategies in wild mammals. In this sense, an important step for the cryopreservation of these samples is to recognize the properties of the skin and cartilage. Thus, knowing that the skin may differ among species and aiming to contribute to the establishment of cryobanks, the study examined the differences in the ear skin and cartilage of wild rodents from South America, agouti (Dasyprocta leporina) and spix's yellow-toothed cavy (Galea spixii). Ultrastructural and quantitative methods were used to measure skin and cartilage thickness, density of collagen and elastic fibers, cell type number and distribution, and proliferative activity. Although ultrastructural analysis revealed a similar pattern between species, morphometric analysis of the skin and cartilage showed differences between agoutis and cavies regarding thickness of epidermis layers (corneum: $5.3 \pm 2.5 \mu \mathrm{m}$ vs. $3.9 \pm 0.6 \mu \mathrm{m}$; intermediate: $16.4 \pm 6.2 \mu \mathrm{m}$ vs. $23.4 \pm 8.1 \mu \mathrm{m}$; basal: $9.9 \pm 2.1 \mu \mathrm{m}$ vs. $4.8 \pm 0.5 \mu \mathrm{m}$ ), dermis $(183.1 \pm 44.0 \mu \mathrm{m}$ vs. $258.2 \pm 22.9 \mu \mathrm{m})$, total skin $(211.8 \pm 46.0 \mu \mathrm{m}$ vs. $290.3 \pm 23.7 \mu \mathrm{m})$ and perichondrium $(27.6 \pm 6.1 \mu \mathrm{m}$ vs. $10.5 \pm 1.8 \mu \mathrm{m})$. A greater number of epidermal cells $(61.7 \pm 15.2$ vs. $24.8 \pm 7.6)$ and chondrocytes ( $32.7 \pm 9.0$ vs. $27.5 \pm 4.7)$ were observed in agouti, while the cavy presented a greater number of melanocytes $(12.6 \pm 4.7$ vs. $29.9 \pm 6.2)$, keratinocytes $(14.7 \pm 4.2$ vs. $29.8 \pm 7.6)$, and fibroblasts (103.6 \pm 24.7 vs. $112.2 \pm 11.3$ ). Moreover, a higher percentage of collagen fibers and proliferative activity was observed in the skin of cavies, when compared to the skin of agoutis. Therefore, there are differences between agouti and cavy for ear skin and cartilage, requiring the establishment of species-specific cryopreservation protocols.
\end{abstract}

INDEX TERMS: Wild rodents, Dasyprocta leporina, Galea spixii, ultrastructure, morphology, morphometry, ear skin, cartilage, cryobanks, wildlife animals.

RESUMO.- [Descrição ultraestrutural e morfométrica da pele e cartilagem auricular de dois roedores histricognatos silvestres da América do Sul (Dasyprocta leporina e Galea spixii)]. A pele e cartilagem têm sido uma importante fonte

\footnotetext{
${ }^{1}$ Received on December 6, 2020.

Accepted for publication on December 26, 2020.

${ }^{2}$ Laboratório de Biotecnologia Animal, Universidade Federal Rural do Semi-Árido (UFERSA), BR-110 Km 47, Presidente Costa e Silva, Mossoró, RN 599625-900, Brazil. *Corresponding author: alexsandra.pereira@ufersa.edu.br

${ }^{3}$ Laboratório de Morfofisiologia Animal Aplicada, Universidade Federal Rural do Semi-Árido (UFERSA), BR-110 Km 47, Presidente Costa e Silva, Mossoró, RN 599625-900, Brazil.
}

de recuperação de células somáticas a serem utilizadas em estratégias de conservação em mamíferos silvestres. Nesse contexto, uma importante etapa para criopreservação é conhecer, inicialmente, as propriedades que compõem a pele e cartilagem. Sabendo, então, que a pele pode diferirse entre espécies e com o objetivo de contribuir para o estabelecimento de criobancos, o estudo evidenciou as diferenças da pele e da cartilagem do pavilhão auricular apical de cutias (Dasyprocta leporina) e preás (Galea spixii) que são roedores silvestres presentes na América do Sul. Para tanto, métodos ultraestruturais e quantitativos foram utilizados para mensurar a espessura da pele e da cartilagem, densidade de 
fibras colágenas e elásticas, número e distribuição dos tipos celulares e atividade proliferativa. Embora as propriedades ultraestruturais em cutias e preás tenham se mostrado semelhantes, avaliações acerca da morfometria da pele e da cartilagem demonstrou diferenças, especialmente nas

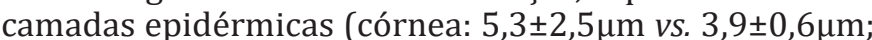
espinhosa: $16,4 \pm 6,2 \mu \mathrm{m}$ vs. $23,4 \pm 8,1 \mu \mathrm{m}$; basal: $9,9 \pm 2,1 \mu \mathrm{m}$ vs. $4,8 \pm 0,5 \mu \mathrm{m})$, derme $(183,1 \pm 44,0 \mu \mathrm{m} v s .258,2 \pm 22,9 \mu \mathrm{m})$, pele total $(211,8 \pm 46,0 \mu \mathrm{m} v s$. $290,3 \pm 23,7 \mu \mathrm{m})$ e pericôndrio $(27,6 \pm 6,1 \mu \mathrm{m} v s .10,5 \pm 1,8 \mu \mathrm{m})$. Além disso, um número maior de células epidérmicas $(61,7 \pm 15,2$ vs. $24,8 \pm 7,6)$ e condrócitos $(32,7 \pm 9,0$ vs. $27,5 \pm 4,7)$ foram observados em cutias, enquanto em preás um maior número de melanócitos $(12,6 \pm 4,7$ vs. $29,9 \pm 6,2)$, queratinócitos $(14,7 \pm 4,2$ vs. $29,8 \pm 7,6)$ e fibroblastos $(103,6 \pm 24,7$ vs. $112,2 \pm 11,3)$ foram evidenciados. Ainda, em preás, uma maior porcentagem de fibras colágenas e da atividade proliferativa foram observadas quando comparadas a pele de cutias. Portanto, existem diferenças entre cutias e preás para pele e cartilagem do pavilhão auricular, exigindo desta forma um estabelecimento de protocolos de criopreservação específica para cada uma destas espécies.

TERMOS DE INDEXAÇÃO: Roedores silvestres, Dasyprocta leporina, Galea spixii, ultraestrutura, morfologia, morfometria, pele auricular, cartilagem, criobancos, animais selvagens.

\section{INTRODUCTION}

Agouti (Dasyprocta leporina) and spix's yellow-toothed cavy (Galea spixii) are histricognate rodents belonging to the Dasyproctidae and Caviidae family, respectively, and distributed throughout the Brazilian territory (Silva et al. 2017). These animals play different roles in the functionality of the environment that they inhabit and are models for rodents under the threat of extinction (Praxedes et al. 2018b), since their populations are stable (Catzeflis et al. 2016, Emmons \& Reid 2016). In other species, the use of an experimental model with a stable population has already been and interesting alternative and an important tool used in animal conservation research programs (Cardoso et al. 2020, Echeverry et al. 2020).

Thus, in order to respond to this demand, for the study of these species, skin and cartilage cryobanks have been established in recent years (Praxedes et al. 2018a, Pereira et al. 2019), since skin and cartilage somatic cells can be used in the multiplication of individuals using cloning (Azuma et al. 2018), in regenerative medicine (Aliborzi et al. 2016), and genetic (Comizzoli 2017) and morphological research (Mario et al. 2018). The first step in the establishment of a skin and cartilage cryobank is to establish a protocol for tissue cryopreservation that results in minimal cell damage (Machado et al. 2017). Therefore, the identification of ear skin and cartilage similarities and differences among the species is a determining step for choosing the best method for successful cryopreservation.

In general, protocols used in wild mammals are developed in phylogenetically close species. In 2020, our group established a protocol for cryopreserving the skin and cartilage of agoutis using vitrification and a combination of dimethyl sulfoxide and ethylene glycol as cryoprotectants (Costa et al. 2020). Thus, to establish a cryopreservation protocol for cavy tissues, using agouti as the reference species, we initially aimed to recognize the similarities and differences of the skins and cartilages of these two species. We specifically examined the ultrastructure and composition of the skin and cartilage of the South American rodents' agouti and spix's yellow-toothed cavy, for the establishment of suitable biological resource banks for these species.

\section{MATERIALS AND METHODS}

Except where indicated, all chemicals, media, and solutions were purchased from Sigma Chemical Co. (St. Louis/MO, USA), GibcoBRL (Carlsbad/CA, USA), and Labimpex (São Paulo/SP, Brazil). All experimental protocols and animal care were approved by the Animal Ethics Committee of the "Universidade Federal Rural do Semi-Árido" (CEUA-UFERSA, no. 23091.001072/2015-92 and no. 23091.010566/2017-20), and the "Instituto Chico Mendes de Conservação da Biodiversidade" (ICMBio; no. 48633-2 and no. 604281).

Animals, ear cartilage, and skin collection.Eight male agoutis (Dasyprocta leporina; 8 months old) and eight male spix's yellowtoothed cavy (Galea spixii; 8 months old) obtained from the Center for Multiplication of Wild Animals (no. 1478912) were used in this study. The animals were previously anesthetized by intramuscular administration of $15 \mathrm{mg} / \mathrm{kg}$ ketamine hydrochloride (Ketalar; Pfizer, São Paulo/SP, Brazil) and 1mg/kg xylazine hydrochloride (Rompun; Bayer, São Paulo/SP, Brazil), according to Castelo et al. (2015). Ear margin tissues $\left(1-2 \mathrm{~cm}^{2}\right)$ were obtained using pliers and transported to the laboratory in Dulbecco's modified Eagle's medium (DMEM) supplemented with $2 \%$ antibiotic-antimycotic solution (penicillin $\mathrm{G}$, streptomycin, and amphotericin B) at $37^{\circ} \mathrm{C}$ for $1 \mathrm{~h}$.

In the laboratory, tissues were washed in $70 \%$ ethanol, and by using a scalpel blade and a cutting mold, eight fragments $\left(9.0 \mathrm{~mm}^{3} ; 3 \times 3 \times\right.$ $1 \mathrm{~mm}$ ) per individual per species were obtained and were equally and randomly allocated for ultrastructural and morphometric analyses.

Processing and ultrastructural analysis. Initially, two fragments from each individual were fixed in $2.5 \%$ glutaraldehyde solution in phosphate-buffered saline (PBS) for five days. After this period, tissues were post-fixed in 1\% osmium tetroxide diluted in distilled water and dehydrated with increasing concentrations of ethanol (Ciena et al. 2017). For scanning electron microscopy analysis, samples were conditioned in the drying equipment to the critical point of carbon dioxide (K850 Critical Point Dryer; Quorum Technologies, Lewes, East Sussex, United Kingdom), placed in a stub, and metallized with gold. Finally, tissue ultrastructure was visualized using a scanning electron microscope (TESCAN VEGA3; Tescan Analytics, Fuveau, Bouches-du-Rhône, France).

Processing and morphometric analysis using histological staining. Initially, six fragments from each individual were fixed in a $4 \%$ paraformaldehyde solution in PBS for a period of seven days. After this period, tissues were dehydrated in increasing concentrations of ethanol, diaphanized in xylol, included and embedded in paraffin, and sectioned in $5.0 \mu \mathrm{m}$, according to Costa et al. (2020). All morphometric analyses were performed using a light microscope (Olympus CX 31 RBSFA; Tokyo, Japan) and ImageJ software (US National Institutes of Health; Bethesda, Rockville, USA).

Sections were stained with hematoxylin and eosin (HE) according to Costa et al. (2020), and the following parameters were examined: epidermal, dermal, and perichondrium thickness (in $\mu \mathrm{m}$ ); thickness of epidermis layers; and number and distribution of melanocytes, keratinocytes, epidermal cells (Merkel and Langerhans cells), fibroblasts, and chondrocytes. For all analyses, 20 images per animal were acquired in $400 \times$ magnification, totaling 160 images per species.

Other sections were stained with Gomori trichrome (GT), according to Borges et al. (2017) for evaluation of the density of collagen 
fibers. Briefly, in each image, an area of the superficial dermis with collagen fibers was selected where the following parameters were evaluated and compared: image area $\left(\mu \mathrm{m}^{2}\right)$, collagen area $\left(\mu \mathrm{m}^{2}\right)$, and percentage of collagen (density) calculated as total area with collagen fibers divided by the total area of the analyzed section (Morais et al. 2017). For all analyses, 10 images per animal were acquired in $400 \times$ magnification, totaling 80 images per species.

Moreover, sections were stained with Weigert-Van Gieson iron hematoxylin (WG; basic resorcin-fuchsin) (Hernández-Morera et al. 2017) for visualization of the density of elastic fibers. For viewing, one image per animal was acquired in $1000 \times$ magnification.

Finally, for assessment of the cell proliferative potential using the argyrophilic nucleolar organizer region (AgNOR) method, sections were placed in silver solution prepared by mixing 1 part of $2 \%$ gelatin in $1 \%$ aqueous formic acid and 2 parts of $50 \%$ aqueous silver nitrate solution, and the slides were incubated in the dark for $30 \mathrm{~min}$ (Queiroz Neta et al. 2018). Subsequently, the slides were washed in 3\% sodium thiosulfate solution and 3\% sodium metabisulfite solution for $10 \mathrm{~min}$ each. For all analyses, 10 images per animal were acquired in $1000 \times$ magnification, totaling 80 images per species. For the analyses of each slide, the AgNOR dots were counted in 100 fibroblasts by Image Pro-Plus software AgNOR number/cell and AgNOR area/cell were calculated.

Statistical analysis. Data were expressed as mean \pm standard error (one animal/repetition) and analyzed using the GraphPad software (Graph-Pad Software Incorporation; La Jolla, CA, USA). All results were verified for normality by the Shapiro-Wilk test and homoscedasticity by the Levene's test. As the data regarding the density of collagen fibers did not show a normal distribution, they were arcsine transformed. Data were analyzed by ANOVA (multiple comparisons) followed by Tukey's test. The results of AgNOR analysis, and cell numbers were analyzed by Kruskal-Wallis and Dunn tests. Significance was set at $\mathrm{P}<0.05$.

\section{RESULTS}

\section{Evaluation of ear skin and cartilage using ultrastructural analysis}

Using scanning electron microscopy, the ultrastructural analysis of the ear skin of these rodents proved to be similar (Fig.1A,F). The structural pattern of the skin and cartilage tissue could be confirmed, later, from the morphological evaluation of this region in the present study. Thus, about the skin of agouti and spix's yellow-toothed cavy, the corneum layer, which is the most superficial, containing dead cells and with constant cellular detachment, was shown evident in the epidermis (Fig.1B,G). On the other hand, for the delimitation of the dermis, the presence of fiber bundles (Fig.1C,H) and hair follicles (Fig.1D,I) were observed, which are structural components of the region. While in the cartilaginous tissue of these small rodents, gaps were identified that are the insertion sites of chondrocytes, cells responsible for maintaining the cartilaginous matrix (Fig.1E,J).

\section{Evaluation of ear skin and cartilage using morphometric analysis}

The skin is one of the largest organs and performs numerous functions for mammals. In this organ it is possible to show cells of great biotechnological impact and for this reason it has been constantly used in recent years as an alternative for scientific studies. Based on this principle, the skin of agoutis and spix's yellow-toothed cavy morphologically showed similar characteristics. This is because in both species, the skin
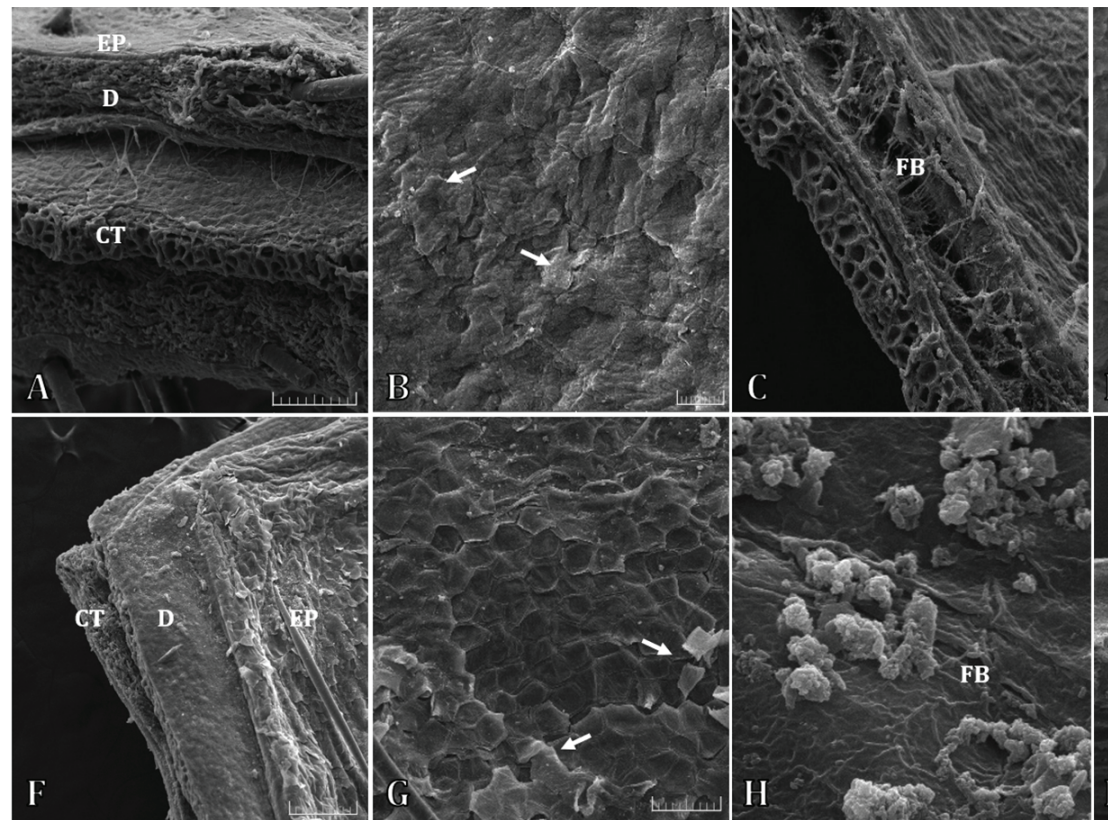
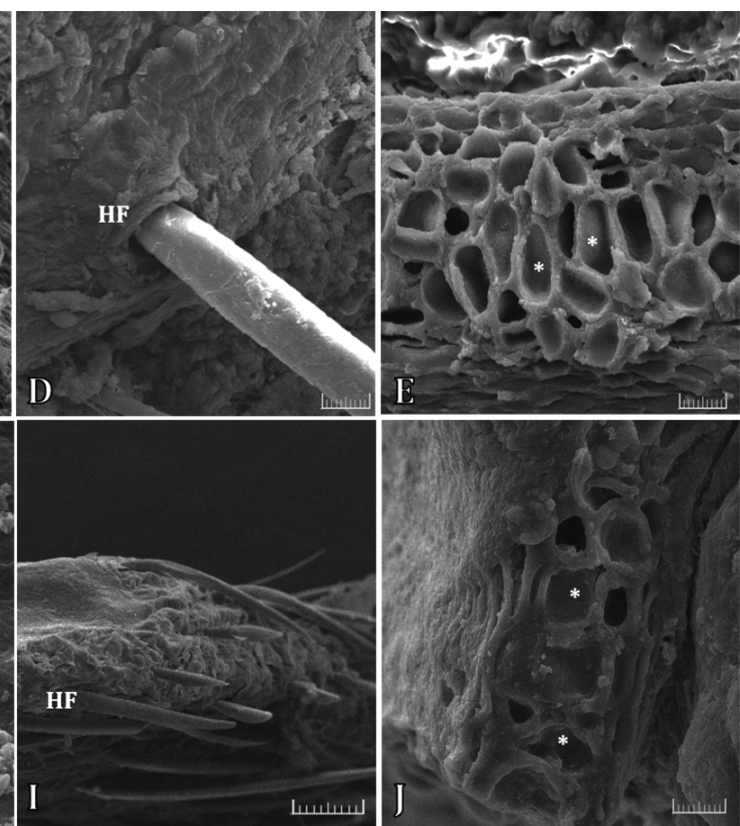

Fig.1. Ultrastructural analysis by scanning electron microscopy of the ear skin and cartilage derived from (A-E) agoutis and (F-J) spix's yellow-toothed cavy. (A,F) Represent and overview of the skin with its layers and cartilaginous tissue. $(\mathbf{A}) \mathrm{Bar}=10 \mu \mathrm{m},(\mathbf{F}) \mathrm{bar}=200 \mu \mathrm{m}$. Epidermis (EP), dermis (D) and cartilaginous tissue (CT). $(\mathbf{B}, \mathbf{G})$ Represent the corneum layer (arrows) of epidermis of skin. $(\mathbf{B})$ Bar $=$ $20 \mu \mathrm{m},(\mathbf{G})$ bar $=100 \mu \mathrm{m}$. (C,H) Representation of dermal fiber bundles (FB). (C) Bar $=100 \mu \mathrm{m},(\mathbf{H})$ bar $=5 \mu \mathrm{m}$. (D,I) Representation of the hair follicle (HF) in the skin dermis. (D) Bar $=20 \mu \mathrm{m},(\mathbf{I})$ bar $=200 \mu \mathrm{m}$. (E,J) Represent the cartilaginous tissue, where lacunae $(*)$ are observed. Bar $=20 \mu \mathrm{m}$. 
was composed of two layers, the epidermis and the dermis (Fig.2A,D). Specifically, in the epidermis of these rodents, three layers were observed, the basal and spinosum of which make up the viable portion and contained different cell types, such as melanocytes, keratinocytes, Merkel and Langerhans cells
(Fig.2B,E). Additionally, in the epidermis, the unviable part known as the corneum layer was also observed, in which it consists of dead cells, without nucleus and with a keratinrich cytoplasm, and for this reason it is called a keratinized stratified epithelium (Fig.2B,E).
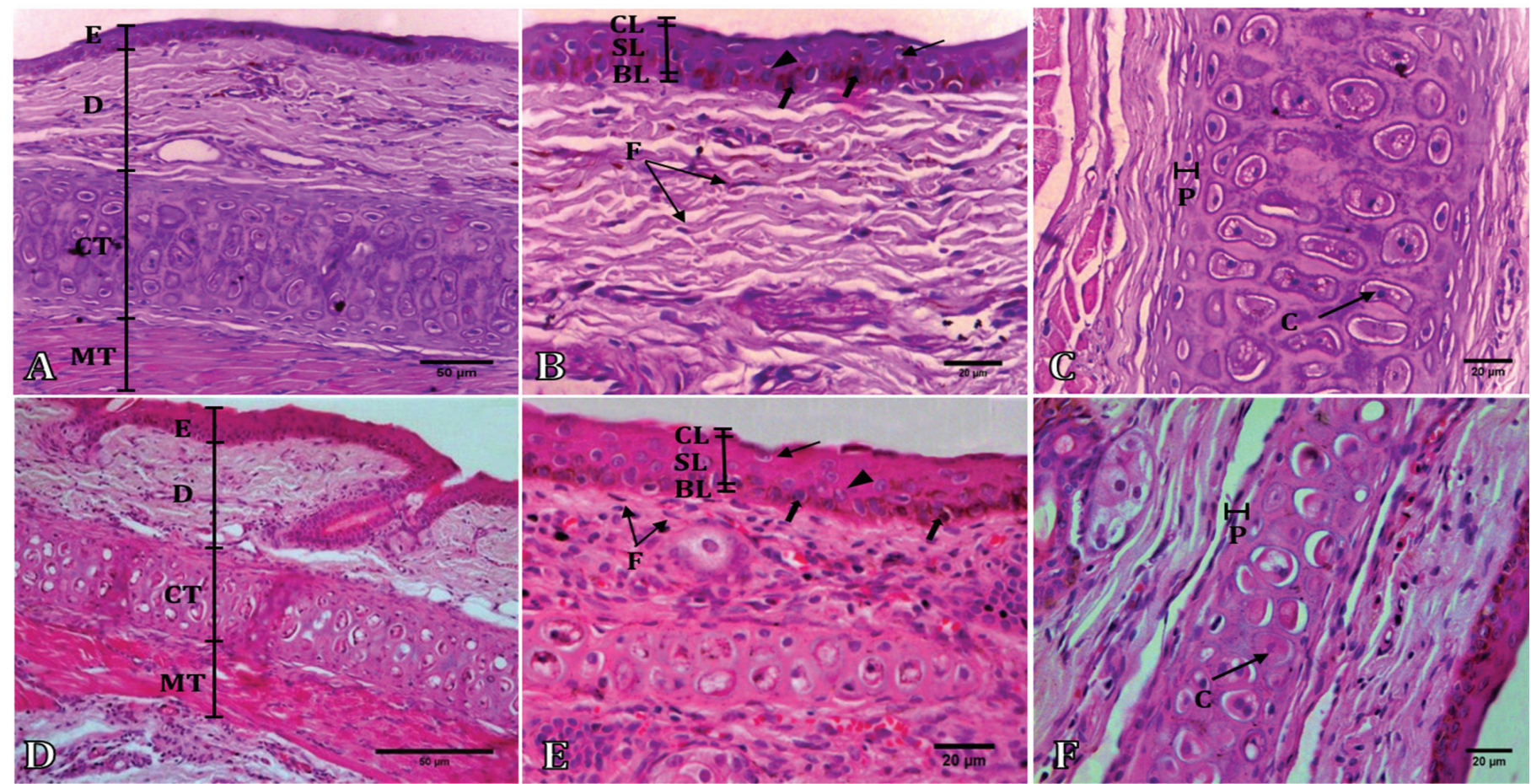

350

- Dasyprocta leporina

Galea spixii

300

250

$\underbrace{\text { 总 }}_{\text {兽 }} 200$

100

G
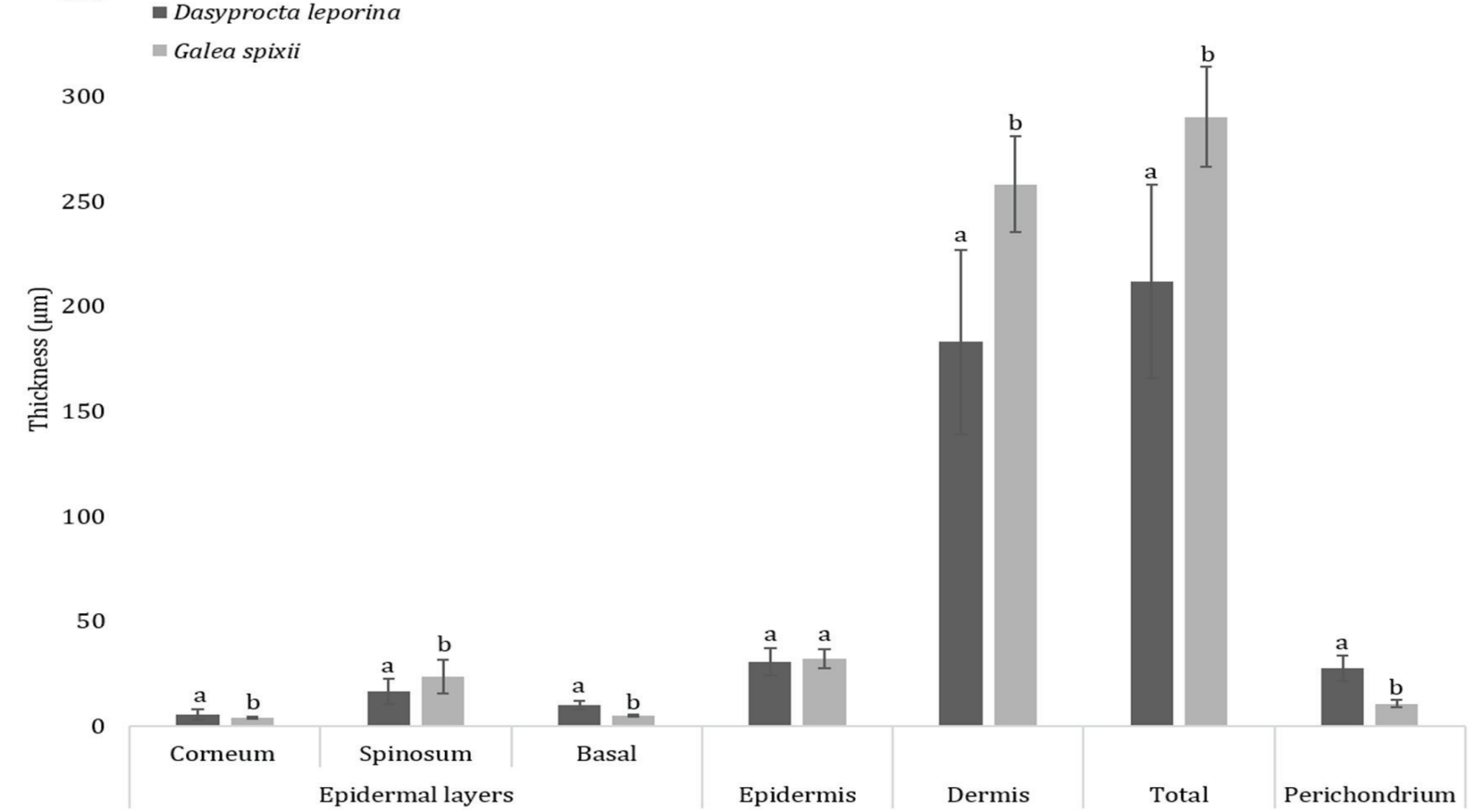

Fig.2. Histological analysis using HE of the ear skin and cartilage derived from (A-C) agoutis and (D-F) spix's yellow-toothed cavy. (A,D) Represent and overview of the skin layers. HE, obj.20x, bar $=50 \mu \mathrm{m}$. (B,E) Represent the epidermis layers and dermis. HE, obj.40x, bar $=20 \mu \mathrm{m}$. (C,F) Represent the cartilage. HE, obj.40x, bar $=20 \mu \mathrm{m}$. Epidermis (E), dermis (D), cartilaginous tissue (CT), muscle tissue (MT), corneum layer (CL), spinosum layer (SL), basal layer (BL), keratinocyte (triangle), melanocyte (thick arrow), epidermal cell (fine arrow), fibroblast (F), chondrocyte $(\mathrm{C})$ and perichondrium (P). (G) Measurement of the thickness of the skin and cartilage. Bars indicate standard deviation. ${ }^{a, b}$ Values with different superscripts differ $(P<0.05)$. 
Regarding the dermis of the skin of agouti and spix's yellowtoothed cavy, it was possible to highlight the connective tissue rich mainly in collagen fibers, although it was not possible to observe a clear distinction between the papillary dermis, which is made up of recesses that increase the contact zone between the epidermis, and neither the reticular dermis, which is thicker and deeper, constituted mainly by the sebaceous and sweat glands. Additionally, although in the dermis of agoutis and spix's yellow-toothed cavy other cell types have not been found, fibroblasts have been identified which are the main cell type in this region. Therefore, allowing from this structural pattern of the skin, to characterize it as thin for both species.

Also, in somatic samples of agoutis and spix's yellow-toothed cavy, a specialized form of connective tissue was also found that promotes numerous functions, but the coating and support of surfaces is one of its main, known as cartilaginous tissue (Fig.2C,F). Thus, in the cartilaginous tissue, a cartilaginous matrix has been identified, composed of gaps that are the sites in which chondrocytes, the main cell type of this tissue resides. Additionally, the perichondrium that is responsible for nutrition, oxygenation and elimination of cellular metabolites has also been identified. Therefore, confirming that the structural pattern of the skin and cartilaginous tissue of agoutis and spix's yellow-toothed cavy were similarly as previously identified in the ultrastructural evaluation.

For morphometric analysis of the skin and cartilage tissue, initially differences were shown in the thickness of the epidermal layers of agouti and spix's yellow-toothed cavy (corneum: $5.3 \pm 2.5 \mu \mathrm{m} v$ s. $3.9 \pm 0.6 \mu \mathrm{m}$; spinosum: $16.4 \pm 6.2 \mu \mathrm{m}$ vs. $23.4 \pm 8.1 \mu \mathrm{m}$; basal: $9.9 \pm 2.1 \mu \mathrm{m} v s .4 .8 \pm 0.5 \mu \mathrm{m})$, dermis $(183.1 \pm 44.0 \mu \mathrm{m} v$ v. $258.2 \pm 22.9 \mu \mathrm{m})$, total skin $(211.8 \pm 46.0 \mu \mathrm{m}$ vs. $290.3 \pm 23.7 \mu \mathrm{m})$ and the perichondrium of the cartilage (27.6 $\pm 6.1 \mu \mathrm{m} v s .10 .5 \pm 1.8 \mu \mathrm{m})$ (Fig.2G). In addition, a greater number of epidermal cells $(61.7 \pm 15.2$ vs. $24.8 \pm 2.4)$ and chondrocytes $(32.7 \pm 9.0 \mathrm{vs}$. $27.5 \pm 4.7)$ in the skin and cartilage agoutis were found when quantification was performed, although a greater number of melanocytes, keratinocytes and fibroblasts was observed in the skin of spix's yellow-toothed cavy (Table 1).

Regarding the density of fibers in the dermis of these two rodents (Fig.3A,B), a higher density of collagen fibers in the

Table 1. Quantification of cell numbers in ear skin and cartilaginous tissue derived from agoutis (Dasyprocta leporina) and spix's yellow-toothed cavies (Galea spixii)

\begin{tabular}{|c|c|c|c|c|c|c|c|c|c|c|}
\hline \multirow{2}{*}{ Rodent } & \multicolumn{2}{|c|}{ Melanocytes } & \multicolumn{2}{|c|}{ Keratinocytes } & \multicolumn{2}{|c|}{ Epidermal cells } & \multicolumn{2}{|c|}{ Fibroblasts } & \multicolumn{2}{|c|}{ Chondrocytes } \\
\hline & Mean \pm SD & Range & Mean \pm SD & Range & Mean \pm SD & Range & Mean \pm SD & Range & Mean \pm SD & Range \\
\hline D. leporina & $12.6 \pm 4.7^{a}$ & $0-29$ & $14.7 \pm 4.2^{\mathrm{a}}$ & $6-29$ & $61.7 \pm 15.2^{\mathrm{a}}$ & $29-132$ & $103.6 \pm 24.7^{a}$ & $43-171$ & $32.7 \pm 9.0^{\mathrm{a}}$ & $16-69$ \\
\hline G. spixii & $29.9 \pm 6.2^{b}$ & 10-93 & $29.8 \pm 7.6^{b}$ & $7-93$ & $24.8 \pm 2.4^{b}$ & $14-40$ & $112.2 \pm 11.3^{b}$ & $29-187$ & $27.5 \pm 4.7^{b}$ & $6-48$ \\
\hline
\end{tabular}

Data are expressed as mean \pm standard deviation (SD); ${ }^{\text {a,b }}$ Within a column, values with different superscripts differ $(P<0.05)$.

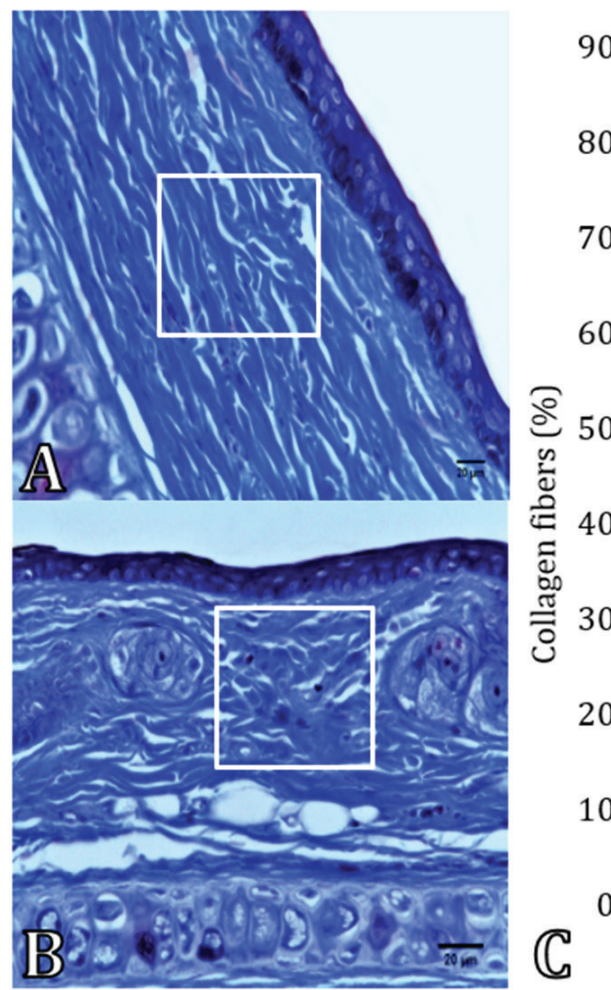

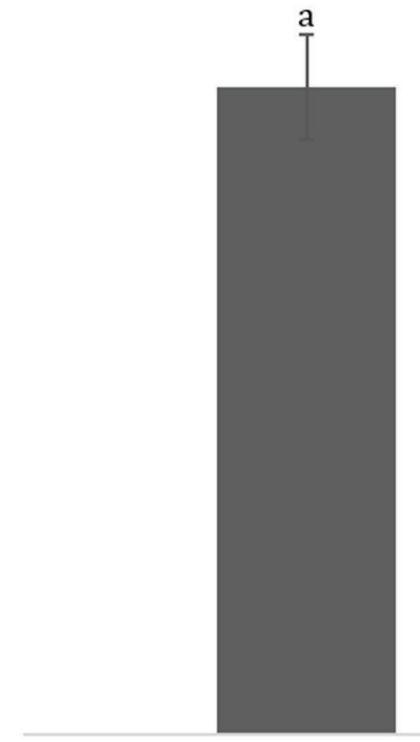

Dasyprocta leporina

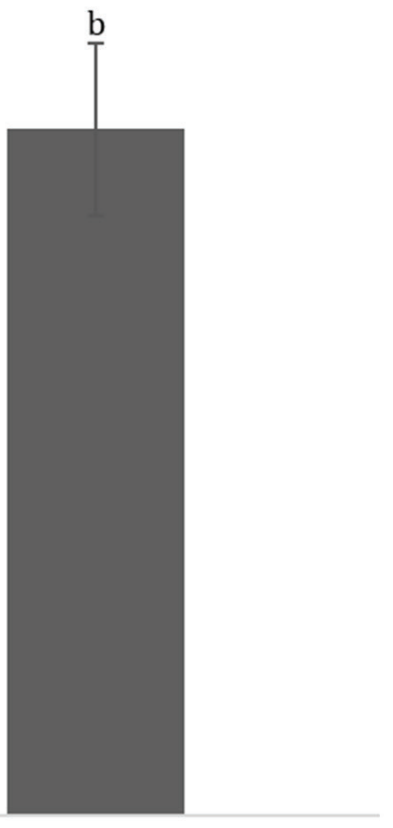

Galea spixii

Fig.3. Quantification of collagen fibers matrix of the skin and cartilage of the agouti (Dasyprocta leporina) and spix's yellow-toothed cavy (Galea spixii) ear skin using GT. (A) Represent agouti skin. GT, obj.40x, bar = 20 $\mu \mathrm{m}$. (B) Represent spix's yellow-toothed cavy skin. GT, obj.40x, bar $=20 \mu \mathrm{m}$. (C) Represent the percentage of collagen fibers present in the dermis of agoutis and spix's yellow-toothed cavy. Bars indicate standard deviation. ${ }^{\mathrm{a}, \mathrm{b}}$ Values with different superscripts differ $(P<0.05)$. 
skin of spix's yellow-toothed cavy compared to agoutis was observed (Fig.3C). In contrast, low density of elastic fibers for both species were identified, which is why quantification has not been performed (Fig.4).

Finally, a higher percentage of the proliferative activity of fibroblasts in the skin of agouti compared to the fibroblasts of the skin of spix's yellow-toothed cavy was quantified (Fig.5). Thus, the proliferative potential was determined as $1.69 \pm 0.68$ and $1.36 \pm 0.15 \mathrm{AgNOR} /$ cell for agoutis and spix's yellow-toothed cavy, respectively (Fig.5C). While the area of AgNOR/cell was $3.15 \pm 1.57$ and $1.01 \pm 0.13 \mu \mathrm{m}^{2}$ for agoutis and spix's yellow-toothed cavy (Fig.5D).
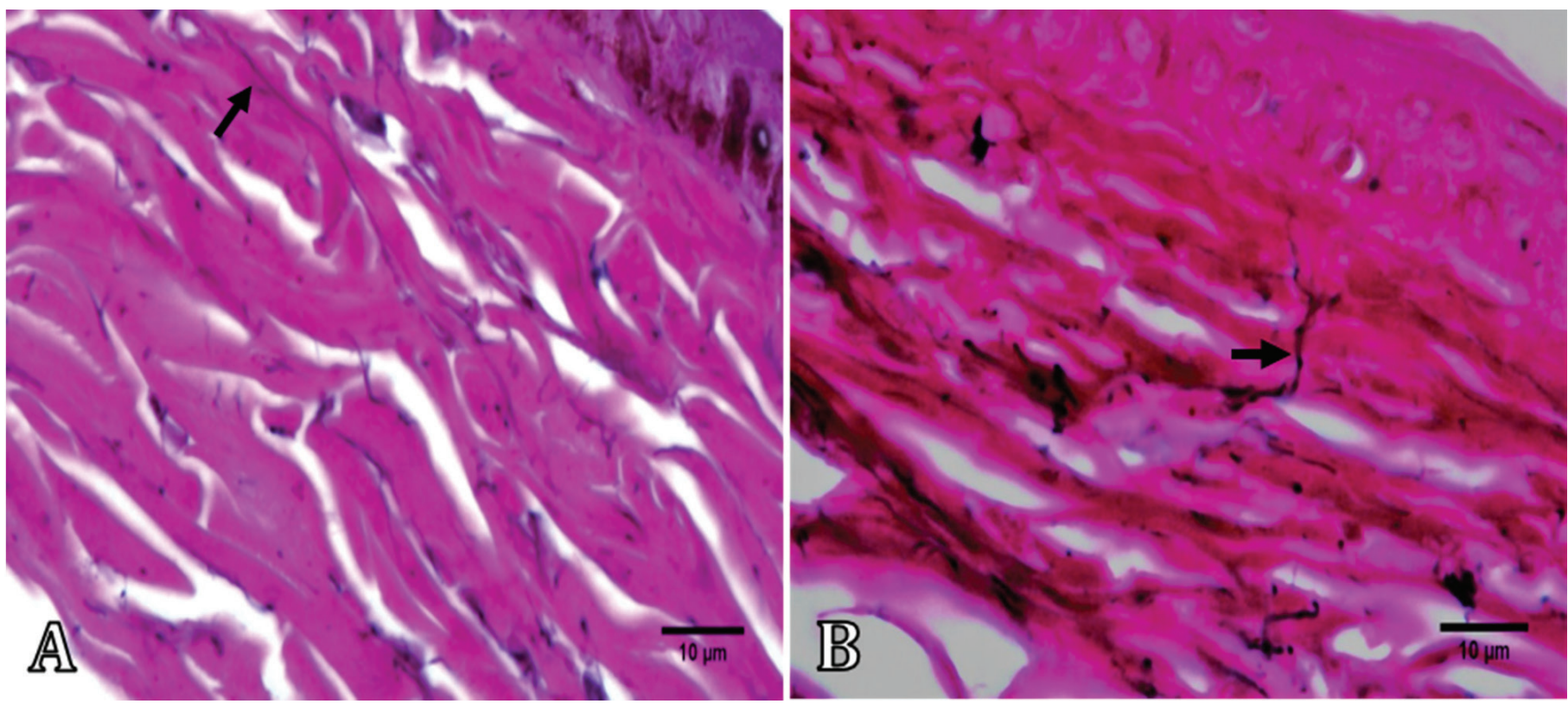

Fig.4. Visualization of the elastic fiber's matrix in the agouti (Dasyprocta leporina) and spix's yellow-toothed cavy (Galea spixii) ear skin stained with WG. (A) Represent agouti skin. WG, obj.100x, bar $=10 \mu \mathrm{m}$. (B) Represent spix's yellow-toothed cavy skin. WG, obj.100x, bar $=10 \mu \mathrm{m}$. Elastic fiber (arrow).

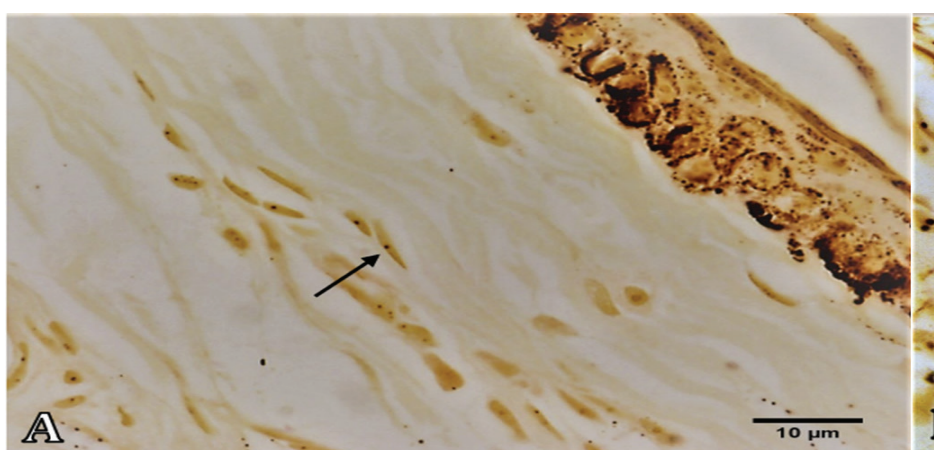

$\mathrm{N}^{\circ}$ AgNOR/cell

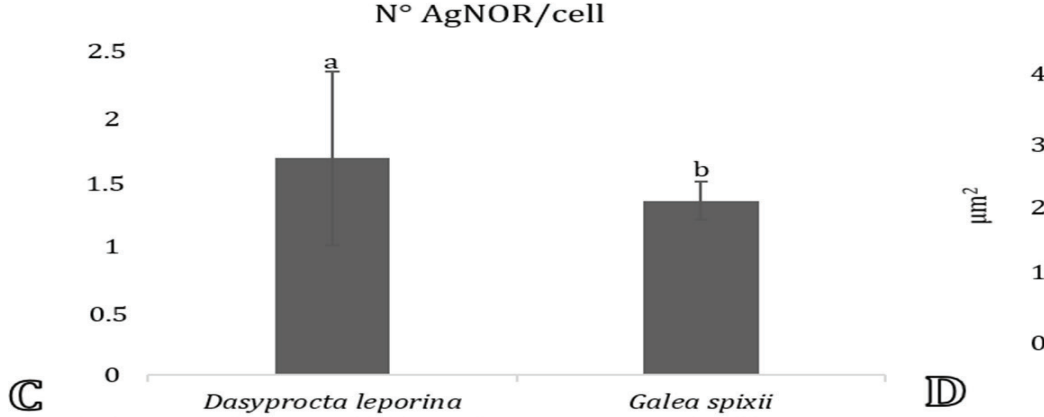

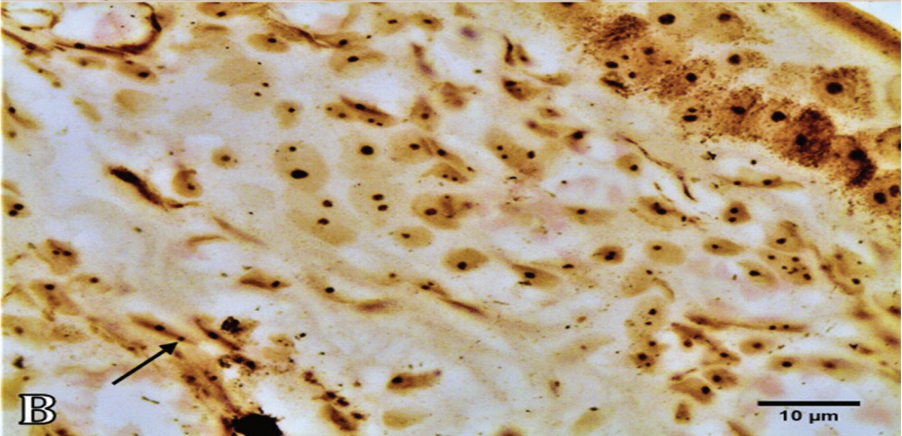

Area AgNOR/cell

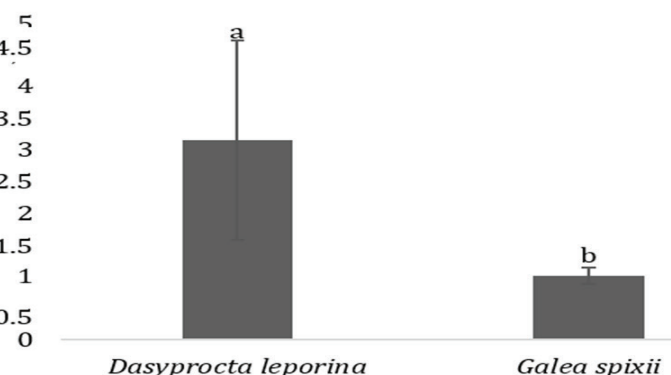

Fig.5. Proliferative activity of ear skin derived from agouti (Dasyprocta leporina) and spix's yellow-toothed cavy (Galea spixii). (A) Staining of AgNOR in the fibroblast from agouti (D. leporina). AgNOR, obj.100x, bar $=10 \mu \mathrm{m}$. (B) Staining of AgNOR in the fibroblasts from and spix's yellow-toothed cavy (G. spixii). AgNOR, obj.100x, bar $=10 \mu \mathrm{m}$. AgNOR present in the fibroblast nucleus (arrow). (C) Quantification of AgNOR number/cell. (D) Quantification of AgNOR area/cell. Bars indicate standard deviation. ${ }^{\text {a,b }}$ Values with different superscripts differ $(P<0.05)$. 


\section{DISCUSSION}

In this study, using the structure of the agouti (Dasyprocta leporina) ear skin and cartilage as a reference, we examined the spix's yellow-toothed cavy (Galea spixii) to establish an adequate cryopreservation protocol for their somatic cells. Therefore, we compared the structural patterns of this region between these species, quantified several types of cells and their proliferative activity and showed that they were different. This study may allow the understanding of how the environment could have altered the histological characteristics of the skin and cartilage. One factor that may have promoted these changes is the evolutionary relationships that have contributed to the physiological adaptations of each of these species. This is because a set of skin properties has been shown to change according to the physiological needs of the species, even when present under the same environment (Daly \& Buffenstein 1998). Additionally, other factors such as ultraviolet radiation (Oriá et al. 2003) can also change the skin structure patterns of these small rodents.

Initially, the ultrastructural evaluation of agoutis and spix's yellow-toothed cavy allowed to characterize the ultrastructure of the ear skin and cartilage. In this way, similar characteristics were shown for these two rodents. This is because the skin was revealed, containing the epidermis and dermis. Specifically, in the epidermis, the corneal layer was observed superficially, loosening, since it is composed of dead cells and that are in constant renovation (Abdo et al. 2020). Also, in the skin, the presence of the dermis was highlighted, containing the fibers that give it flexibility and support to the adjacent tissues (Abdo et al. 2020). In general, these characteristics were already expected since the ear skin for mammals in general presents the same patterns of ultrastructural organization (Khavkin \& Ellis 2011, Biggs et al. 2020). Among the species that present the same ultrastructural patterns of the skin, there are pacas (Cuniculus paca) (Isola et al. 2013), naked mole rat (Heterocephalus glaber) (Menon et al. 2019) and mouse (Allen \& Potten 1976) stand out (Morita et al. 1995). Still, this same pattern was also observed in the skin of Cuban crocodile (Crocodylus rhombifer) (Szewczyk \& Stachewicz 2020) and in the skin of humans (Roger et al. 2019). In addition, in this study region, cartilaginous tissue and its gaps, which are the sites from which chondrocytes, cells responsible for maintaining cartilage, were also identified (Fox et al. 2009, Akkiraju \& Nohe 2015). The presence of cartilaginous tissue is important because this type of specialized connective tissue provides support, rigidity and shape for the entire structural architecture of the ear of these small rodents (Vanwanseele et al. 2002).

Regarding the morphological analysis of the skin of agouti and spix's yellow-toothed cavy, only three layers were identified in the epidermal region, the basal, spinosum and corneum. While the granular and lucid layers were not distinguishable. Characteristics were also observed in the skin dermis of these two rodents, where the presence of the papillary and reticular layer was not evident. This is because we are evaluating thin skin, where unlike thick skin it is not always possible to verify the presence of the different layers that form the epidermis as well as the dermis (Browne 2004). In general, in mammals it was observed that the epidermal and dermal proportions of the skin may vary due to the location of the body, as well as the genetic, physiological and epigenetic need of the species to adapt to the environment, since on the thin skin the epidermis and the dermis is less developed when compared to thick skin (Webster \& Webster 1980, Robert et al. 2012, Arda et al. 2014). In wild rodents, variations between thin and thick skin have also been observed, such as common mole mice (Cryptomys hottentotus) and naked mole mice (H. glaber) (Daly \& Buffenstein 1998). In addition, in swine (Moyo et al. 2018), fishing bat (Yin et al. 2011) and in humans (Khalfa et al. 2018) these skin variations from different regions could also be observed.

Moreover, we observed that the thickness of the spinosum layer in the epidermis of spix's yellow-toothed cavy was larger than that of the agouti, unlike the basal layer and the corneum, which were smaller. Despite these variations in the thickness of the layers, significant differences in the thickness of the epidermis between these two species was not evident, demonstrating the existence of specific characteristics in each species (Webster \& Webster 1980). Variations in the thickness of the epidermal layers of the skin of the neck, thorax, and carpus of male and female paca (C. paca) have also been described in the study by Isola et al. (2013). These variations observed in the agouti and spix's yellowtoothed cavy epidermis are important, since they will allow determination of cryoprotective agents that should be used in the cryopreservation of the skin (Praxedes et al. 2020).

In addition, an average of 29.9 melanocytes and 29.8 keratinocytes was observed in the spix's yellow-toothed cavy epidermis for each tissue area evaluated. This value diverged from what was found for agouti skin (12.6 melanocytes and 14.7 keratinocytes). However, epidermal cells, such as Langerhans and Merkel cells, in spix's yellow-toothed cavy were found to be smaller. In general, different cellular proportions of the epidermis have also been observed for other species, such as rodents, felids and domestic mammals, such as the common mole rat (C. hottentotus), naked mole rat (H. glaber) (Daly \& Buffenstein 1998), jaguar (Panthera onca) (Praxedes et al. 2020), cats, dogs (Souza et al. 2009) and pigs (Navarro et al. 2001). This cellular variation observed both in agoutis and spix's yellow-toothed cavy for other species may be associated with the need in the skin to protect itself from the environment, specifically, from ultraviolet rays, since melanin synthesized from melanocytes of the epidermis has this function (Khavkin \& Ellis 2011, Dolka et al. 2014). In addition, another explanation related to this process can be associated with a chain of hormones responsible and regulating the proliferation and differentiation of melanocytes, keratinocytes, Langerhans cells and Merkel (Scholzen et al. 1998), among which the neuropeptide stands out stimulating alpha-melanocyte $(\alpha-\mathrm{MSH})$ that triggers different skin reactions (Souza et al. 2015).

In both species, the main and most abundant cell type in the dermis was fibroblasts. In addition, collagen and elastic fibers in the skin of these two species were also observed, corroborating the results regarding the skin of the tail of the European beaver (Castor fiber) (Dolka et al. 2014) and different regions of the skin of male and female paca (C. paca) (Isola et al. 2013). However, a greater amount of collagen fibers was found in the cavy dermis compared to agoutis. This may be due to the number and collagen synthetic activity of dermal fibroblasts in the skin of spix's yellow-toothed cavy (Khavkin \& Ellis 2011), also justifying the greater thickness of this region when compared to agouti. 
Additionally, in the ear cartilage of agoutis and spix's yellow-toothed cavy, the cartilaginous tissue responsible for the shape and structure of this organ was found to contain mainly chondrocytes, and a layer of connective tissue providing nutrition to the cartilage, known as the perichondrium (Vanwanseele et al. 2002). In agoutis, the number of chondrocytes was higher compared to spix's yellow-toothed cavy. For Wistar rats, 50.4 chondrocytes were observed in the articular cartilage of the distal portion of the tibia, which is different from the number shown in agoutis and cavy (Portinho et al. 2008). These morphological differences in the cartilage of these species may reflect adaptations according to their functional needs (Vanwanseele et al. 2002).

Evaluations were carried out in addition to the proliferative activity of fibroblasts in the dermis of agoutis and spix's yellow-toothed cavy. The AgNOR technique represents the chromosome fragments that are responsible for the synthesis of ribosomal ribonucleic acids (rRNA). This component is essential, as it promotes the starting point for the synthesis of cellular proteins, that is, the capacity or proliferative potential (Chacur et al. 2015). In spix's yellow-toothed cavy, a lower proliferative potential was observed in comparison to what was observed in agoutis. This suggests that although agoutis and spix's yellow-toothed cavy live in the same environment, it is still possible that epigenetic factors may have influenced the potential of the skin fibroblasts in these rodents. This is because it has already been found that in comparative studies on the physiological and adaptive conditions of species under a common environment, they can still diverge, impacting on morphological conditions (Webster \& Webster 1980). This characteristic was relevant, because different proliferative potentials of fibroblasts have already been identified in different studies, such as collared peccaries (Pecari tajacu) (Borges et al. 2017), jaguar (P. onca) (Praxedes et al. 2020) and domestic mammals, such as domestic cat (Felis silvestris catus) (Martins et al. 2020), pigs (Preziosi et al. 2000) and sheep (Chacur et al. 2015).

\section{CONCLUSIONS}

This study highlighted the importance of knowledge about the ear skin and cartilage for agoutis (Dasyprocta leporina) and spix's yellow-toothed cavy (Galea spixii).

Differences regarding the thickness of layers, cell types and numbers, extracellular collagen matrix and proliferative potential were evidenced. The identification of these differences is especially important because it allows us to understand that the protocols for the formation of cryobanks are specific to each species and that they need to be evaluated initially for each one of them.

Acknowledgments.- The authors thank the CEMAS-UFERSA for providing biological material. This study was supported by "Conselho Nacional de Desenvolvimento Científico e Tecnológico" (CNPq) and "Coordenação de Aperfeiçoamento de Pessoal de Nível Superior" (CAPES), Brasil, Financial Code 001. M.F. Oliveira and A.F. Pereira are recipients of CNPq grants.

Conflict of interest statement.- The authors declare that they have no conflict of interest.

\section{REFERENCES}

Abdo J.M., Sopko N.A. \& Milner S.M. 2020. The applied anatomy of human skin: a model for regeneration. Wound Med. 28(2020):100179. <https://dx.doi.org/10.1016/j.wndm.2020.100179>

Akkiraju H. \& Nohe A. 2015. Role of chondrocytes in cartilage formation, progression of osteorarthritis and cartilage regeneration. J. Develop. Biol. 3(4):177-192.<https://dx.doi.org/10.3390/jdb3040177><PMid:27347486>

Aliborzi G., Vahdati A., Mehrabani D., Hosseini S.E. \& Tamadon A. 2016. Isolation, characterization and growth kinetic comparison of bone marrow and adipose tissue mesenchymal stem cells of guinea pig. Int. J. Stem Cells 9(1):115-123. <https://dx.doi.org/10.15283/ijsc.2016.9.1.115> <PMid:27426093>

Allen T.D. \& Potten C.S. 1976. Ultrastructural site variations in mouse epidermal organization. J. Cell Sci. 21(2):341-359. <PMid:972174>

Arda 0., Goksugur N. \& Tuzun Y. 2014. Basic histological structure and functions of facial skin. Clin. Dermatol. 32(1):3-13. <https://dx.doi.org/10.1016/j. clindermatol.2013.05.021><PMid:24314373>

Azuma R., Miyamoto K., Oikawa M., Yamada M. \& Anzai M. 2018. Combinational treatment of trichostatin $\mathrm{A}$ and vitamin $\mathrm{C}$ improves the efficiency of cloning mice by somatic cell nuclear transfer. J. Vis. Exp. (134):e57036. <https://dx.doi.org/10.3791/57036> <PMid:29757287>

Biggs L.C., Kim C.S., Miroshnikova Y.A. \& Wickström S.A. 2020. Mechanical forces in the skin: roles in tissue architecture, stability, and function. J. Invest Dermatol. 140(2):284-290. <https://dx.doi.org/10.1016/j.jid.2019.06.137>

Borges A.A., Bezerra F.V.F., Costa F.N., Queiroz Neta L.B., Santos M.V.O., Oliveira M.F., Silva A.R. \& Pereira A.F. 2017. Histomorphological characterization of collared peccary (Pecari tajacu Linnaeus, 1758) ear integumentary system. Arq. Bras. Med. Vet. Zootec. 69(4):948-954. <https://dx.doi. org/10.1590/1678-4162-9344>

Browne J.V. 2004. Early relationship environments: physiology of skin-to-skin contact for parents and their preterm infants. Clin. Perinatol. 31(2):287298. <https://dx.doi.org/10.1016/j.clp.2004.04.004><PMid:15289033>

Cardoso C.A., Motta L.C.B., Oliveira V.C. \& Martins D.S. 2020. Somatic feather follicle cell culture of the gallus domesticus species for creating a wild bird genetic resource bank. Anim. Reprod. 17(3):e20200044.<https://dx.doi. org/10.1590/1984-3143-ar2020-0044>

Castelo T.S., Silva A.M., Bezerra L.G.P., Costa C.M., Lago A.E.A., Bezerra J.A.B., Campos L.B., Praxedes E.C.G. \& Silva A.R. 2015. Comparison among different cryoprotectants for cryopreservation of epididymal sperm from agouti (Dasyprocta leporina). Cryobiology 71(3):442-447. <https://dx.doi. org/10.1016/j.cryobiol.2015.09.005>

Catzeflis F., Patton J., Percequillo A. \& Weksler M. 2016. Galea spixii, Spix's Yellow-toothed Cavy. The IUCN Red List of Threatened Species. e.T8825A22189453.<https://dx.doi.org/10.2305/IUCN.UK.2016-2.RLTS. T8825A22189453.en>

Chacur M.G.M., Ibrahim D.B., Arrebola T.A.H., Sanches O.C., Giuffrida R., Oba E. \& Ramos A.A. 2015. Evaluation of the AgNOR staining method in ovine testicles. Arq. Bras. Med. Vet. Zootec. 67(2):447-454. <https://dx.doi. org/10.1590/1678-6695>

Ciena A.P., Santos A.C., Vasconcelos B.G., Rici R.E.G., Neto A.C.A., Almeida S.R.Y., Miglino M.A. \& Watanabe I. 2017. Morphological characteristics of papillae and lingual epithelium of guinea pig (Cavia porcellus). Acta Zool. 100(1):1-8. <https://dx.doi.org/10.1111/azo.12230>

Comizzoli P. 2017. Biobankin and fertility preservation for rare and endangered species. Anim. Reprod. 14(1):30-33. <https://dx.doi.org/10.21451/19843143-AR889>

Costa C.A.S., Borges A.A., Nascimento M.B., Aquino L.V.C., Silva A.R., Oliveira M.F. \& Pereira A.F. 2020. Effects of vitrification techniques on the somatic tissue preservation of agouti (Dasyprocta leporina Linnaeus, 1758). Biopreserv. Biobank. 18(3):165-170. <https://dx.doi.org/10.1089/bio.2019.0109> <PMid:32083486> 
Daly T.J.M. \& Buffenstein R. 1998. Skin morphology and its role in thermoregulation in mole-rats, Heterocephalus glaber and Cryptomys hottentotus. J. Anat. 193(4):495-502.<https://dx.doi.org/10.1046/j.1469-7580.1998.19340495.x> <PMid:10029182>

Dolka I., Gizejewska A., Gizejewski Z., Klucinski W. \& Kolodziejska J. 2014. Histological evaluation of selected organs of the eurasian beavers (Castor fiber) inhabiting Poland. Anat. Histol. Embryol. 44(5):378-390. <https://dx.doi.org/10.1111/ahe.12150><PMid:25255694>

Echeverry D.M., Ascenjo P.A., Rojas D.M., Aguilera C.J., Rodríguez-Álvarez L. \& Castro F.0. 2020. Characterization of mesenchymal stem cells derived from adipose tissue of a cougar (Puma concolor). Anim. Reprod. 17(2):e20190109. <https://dx.doi.org/10.1590/1984-3143-ar2019-0109>

Emmons L. \& Reid F. 2016. Dasyprocta leporine, red-rumped agouti. The IUCN Red List of Threatened Species. e.T89497102A22197762. <https:// dx.doi.org/10.2305/IUCN.UK.2016-2.RLTS.T89497102A22197762.en>

Fox A.J.S., Bedi A. \& Rodeo S.A. 2009. The basic Science of articular cartilage: structure, composition, and function. Orthopaedics 1(6):461-468. <https://dx.doi.org/10.1177/1941738109350438> <PMid:23015907>

Hernández-Morera P., Travieso-González C.M., Castaño-González I., Mompeó-Corredera B. \& Ortega-Santana F. 2017. Segmentation of elastic fibers in images of vessel wall sections stained with Weigert's resorcinfuchsin. Comput. Methods Programs Biomed. 142:43-54.<https://dx.doi. org/10.1016/j.cmpb.2017.02.018><PMid:28325446>

Isola J.G.M.P., Moraes P.C., Rahal S.C. \& Machado M.R.F. 2013. Morphology, ultrastructure and morphometry of the tegument of paca (Cuniculus paca Linnaeus, 1766) raised in captivity. Pesq. Vet. Bras. 33(5):674-682.<https:// dx.doi.org/10.1590/S0100-736X2013000500020>

Khalfa H.M., Albideri A. \& Jaffat H.S. 2018. Cytological and histological study of adult and neonate epidermis in thick and thin skin of various anatomical sites. Int. J. Pharm. Qual. Assur. 9(2):174-179. <https://dx.doi. $\operatorname{org} / 10.25258 /$ ijpqa.v9i2.13642>

Khavkin J. \& Ellis D.A.F. 2011. Aging skin: histology, physiology, and pathology. Facial Plast. Surg. Clin. N. Am. 19(2):229-234.<https://dx.doi.org/10.1016/j. fsc.2011.04.003><PMid:21763983>

Machado L.C., Roballo K.C.S., Cury F.S. \& Ambrósio C.E. 2017. Female reproductive system morphology of crab-eating fox (Cerdocyon thous) and cryopreservation of genetic material for animal germplasm bank enrichment. Anat. Histol. Embryol. 46(6):539-546. <https://dx.doi. org/10.1111/ahe.12306> <PMid:28913836>

Mario L.C., Borghesi J., Hayashi R.G., Favaron P.O., Rodrigues M.N., Carvalho R.C. \& Miglino M.A. 2018. Morphology of the Oligoryzomys nigripes respiratory system. Anat. Histol. Embryol. 47(4):364-371. <https://dx.doi.org/10.1111/ ahe.12363><PMid:29869399>

Martins J.C.J., Praxedes E.A., Nascimento M.B., Aquino L.V.C., Alves N.D., Oliveira M.F. \& Pereira A.F. 2020. Comparative study of cryopreservation techniques in somatic tissue of Felis silvestris catus. Res. Soc. Develop. 9(8):e969986676. <https://dx.doi.org/10.33448/rsd-v9i8.6686>

Menon G.K., Catania K.C., Crumrine D., Bradley C. \& Mauldin E.A. 2019. Unique features of the skin barrier in naked mole rats reflect adaptations to their fossorial habitat. J. Morphol. 280(12):1871-1880. <https://dx.doi. org/10.1002/jmor.21072>

Morais G.B., Viana D.A., Silva F.M.O., Xavier Júnior F.A.F., Farias K.M., Pessoa C.D'Ó., Silveira J.A.M., Alves A.P.N.N., Mota M.R.L., Silva F.D.O., Sampaio C.M.S., Verdugo J.M.G. \& Evangelista J.S.A.M. 2017. Polarization microscopy as a tool for quantitative evaluation of collagen using picrosirius red in different stages of CKD in cats. Microsc. Res. Tech. 80(5):543-550. <https://dx.doi. org/10.1002/jemt.22830><PMid:28059480>

Morita K., Hogan M.E., Nanney L.B., King Jr L.E., Manabe M., Sun T.T. \& Sundberg J.P. 1995. Cutaneous Ultrastructural features of the flaky skin ( $f s n)$ mouse mutation. J. Dermatol. 22(6):385-395. <https://dx.doi. org/10.1111/j.1346-8138.1995.tb03412.x><PMid:7650236>
Moyo D., Gomes M. \& Ertlwanger K.H. 2018. Comparison of the histology of the skin of the windsnyer, kolbroek and large white pigs. J. S. Afr. Vet. Assoc. 89(0):e1-e10. <https://dx.doi.org/10.4102/jsava.v89i0.1569> <PMid:30326713>

Navarro F.A., Stoner M.L., Lee H.B., Park C.S., Wood F.M. \& Orgill D.P. 2001. Melanocyte repopulation in full-thickness wounds using a cell spray apparatus. J. Burn Care Rehabil. 22(1):41-46. <https://dx.doi.org/10.1097/00004630200101000-00009><PMid:11227683>

Oriá R.B., Fernandes M.R., Ferreira F.V.A., Brito G.A.C. \& Santana E.N. 2003. Study of age-related changes in human skin using histomorphometric and autofluorescence approaches. An. Bras. Dermatol. 78(4):425-434. <https://dx.doi.org/10.1590/S0365-05962003000400004>

Pereira A.F., Borges A.A., Santos M.V.O. \& Lira G.P.O. 2019. Use of cloning by nuclear transfer in the conservation and multiplication of wild mammals. Revta Bras. Reprod. Anim. 43(2):242-247.

Portinho D., Boin V.G. \& Bertolini G.R.F. 2008. Effects of immobilization and remobilization on bone tissue and cartilage in Wistar rats. Revta Bras. Med. Esporte 14(5):408-411. <https://dx.doi.org/10.1590/S151786922008000500001>

Praxedes E.A., Borges A.A., Santos M.V.O. \& Pereira A.F. 2018a. Use of somatic cell banks in the conservation of wild felids. Zoo Biol. 37(4):258-263. <https://dx.doi.org/10.1002/zoo.21416><PMid:29722907>

Praxedes E.A., Queiroz Neta L.B., Borges A.A., Silva M.B., Santos M.V.O., Ribeiro L.R., Silva H.V.R. \& Pereira A.F. 2020. Quantitative and descriptive histological aspects of jaguar (Panthera onca Linnaeus, 1758) ear skin as a step towards formation of biobanks. Anat. Histol. Embryol. 49(1):121129. <https://dx.doi.org/10.1111/ahe.12500>

Praxedes E.C.G., Peixoto G.C.X., Silva A.M. \& Silva A.R. 2018b. Reproduction in agouti (Dasyprocta spp.): a review of reproductive physiology for developing assisted reproductive techniques. Anim. Reprod. 15(4):1181-1192. <https:// dx.doi.org/10.21451/1984-3143-AR2018-0058>

Preziosi R., Sarli G. \& Marcato P.S. 2000. Cell proliferation and apoptosis in the pathogenesis of oesophagogastric lesions in pigs. Res. Vet. Sci. 68(2):189196. <https://dx.doi.org/10.1053/rvsc.1999.0359><PMid:10756138>

Queiroz Neta L.B., Lira G.P.O., Borges A.A., Santos M.V.O., Silva M.B., Oliveira L.R.M., Silva A.R., Oliveira M.F. \& Pereira A.F. 2018. Influence of storage time and nutrient medium on recovery of fibroblast-like cells from refrigerated collared peccary (Pecari tajacu Linnaeus, 1758) skin. In Vitro Cell Develop. Biol. Anim. 54(7):486-495. <https://dx.doi.org/10.1007/s11626-018-0270-6> $<$ PMid:29923165>

Robert L., Robert-Labat J. \& Robert A.-M. 2012. Physiology of skin aging. Clin. Plast. Surg. 39(1):1-8. <https://dx.doi.org/10.1016/j.cps.2011.09.006> $<$ PMid:22099844>

Roger M., Fullard N., Costello L., Bradbury S., Markiewicz E., O’Reilly S., Darling N., Ritchie P., Maatta A., Karakesisoglou I., Nelson G., Zglinick T., Dicolandrea T., Isfort R., Bascom C. \& Przyborski S. 2019. Bioengineering the microanatomy of human skin. J. Anat. 234(4):438-455. <https://dx.doi. org/10.1111/joa.12942><PMid:30740672>

Scholzen T., Armstrong C.A., Bunnett T.A., Olerud L.J.E. \& Ansel J.C. 1998. Neuropeptides in the skin: Interactions between the neuroendocrine and the skin immune systems. Exp. Dermatol. 7(2/3):81-96. <https://dx.doi. org/10.1111/j.1600-0625.1998.tb00307.x><PMid:9583747>

Silva A.R., Silva A.M., Praxedes C.G. \& Pereira A.F. 2017. Conservation of South American wild hystricognath rodents using reproductive strategies. Revta Bras. Reprod. Anim. 41(1):231-236.

Souza K.S., Cantaruti T.A., Azevedo Jr G.M., Galdino D.A.A., Rodrigues C.M., Costa R.A., Vaz N.M. \& Carvalho C.R. 2015. Improved cutaneous wound healing after intraperitoneal injection of alpha-melanocyte-stimulating hormone. Exp. Dermatol. 24(3):198-203. <https://dx.doi.org/10.1111/ exd.12609><PMid:25431356> 
Souza T.M., Fighera R.A., Kommers G.D. \& Barros C.S.L. 2009. Histological aspects of canine and feline skin as a tool for dermatopathology. Pesq. Vet. Bras 29(2):177-190. <https://dx.doi.org/10.1590/S0100-736X2009000200017>

Szewczyk P.K. \& Stachewicz U. 2020. Collagen fibers in crocodile skin and theeth: a morphological comparison using light and scanning electron microscopy. J. Bionic Eng. 17(2020):669-676. <https://dx.doi.org/10.1007/s42235-020-0059-7>

Vanwanseele B., Lucchinetti E. \& Stussi E. 2002. The effects of immobilization on the characteristics of articular cartilage: current concepts and future directions. Osteoarthr. Cartil. 10(5):408-419. <https://dx.doi.org/10.1053/ joca.2002.0529><PMid:12027542>

Webster D.B. \& Webster M. 1980. Morphological adaptations of the ear in the Rodent family Heteromyidae. Am. Zool. 20(1):247-254. <https://dx.doi. org/10.1093/icb/20.1.247>

Yin J., Wang H., Racey P. \& Zhang S. 2011. Microanatomy of the fishing bat skin. Pakistan J. Zoo. 43(2):387-392. 